\title{
Bioelectricity-generating behavior of a chemically modified carbon black anode in microbial fuel cells
}

\author{
Xinhong Peng*, Xizhang Chu, Wei Liu, Shenghui Wang, Yi Zou, Xiaonan Wang \\ Institute of Seawater Desalination and Multipurpose Utilization, State Oceanic Administration (SOA), Tianjin 300192, China
}

\section{A R T I C L E I N F O}

Article history:

Received 12 January 2015

Accepted 22 April 2015

Published 20 August 2015

\section{Keywords:}

Microbial fuel cell

Chemical activation

Magnetite addition

Anodic capacitance

Power behavior

\begin{abstract}
A B S T R A C T
The poor stability of the current output in microbial fuel cells (MFCs) inhibits its development and application on a large scale. In this work, a carbon black (CB) MFC anode was chemically activated using $\mathrm{HNO}_{3}$ and $\mathrm{KOH}$ as pretreatment agents at low temperature, and further modification was made by $\mathrm{Fe}_{3} \mathrm{O}_{4}$ addition to the host $\mathrm{CB}$ matrix. The enhanced anodic capacitance contributes to a steady power output with neither overshoot nor undershoot below $1.1 \mathrm{~F} / \mathrm{cm}^{2}$. This resulted from the introduction of oxygen(nitrogen)-associated functionalities and the improvement of the surface wettability by the activation treatment. The chemical modification of a CB anode provides a feasible way to optimize power production and anodic capacitance in MFCs.
\end{abstract}

(C) 2015, Dalian Institute of Chemical Physics, Chinese Academy of Sciences. Published by Elsevier B.V. All rights reserved.

\section{Introduction}

Microbial fuel cells (MFCs) which implement the concept of green chemistry are an emerging renewable energy technology that directly use waste biomass to produce electrical energy by the catalytic reaction of exoelectrogenic bacteria, oxidization of organic compounds to $\mathrm{CO}_{2}$ and conduction of electrons to an cathode through an external circuit [1,2]. As potential technology, MFCs have drawn increasing attention in recent years, and progress has been achieved with the promise of practical application, especially for wastewater treatment [3-5], chemical synthesis [6], biochemical oxygen demand (BOD) detection [7], and seawater desalination [8]. However, a high capital cost and unsteady power behavior hinder the development of MFCs on a large scale due to the occurrence of current overshoot. The anode performance is one critical factor due to its low electrochemical capacitance [9] and non-maturing biofilm [10]. To address these problems, efforts had been made in previous studies [11-13] for getting steady MFC performance.

Anode materials with different capacitance for biomass retention were investigated in a MFC process study. It was found that there was no current overshoot phenomenon with an ultra-capacitor activated carbon (UAC) which store electrons as an electro-chemical mediator [9]. However, the high cost and complex preparation procedure of the UAC limit MFC application in practice. The weak conductivity is also a limit for electron transfer between the anode and bacteria. The future MFC anode requires a highly efficient and low cost electrode material. Carbon black (CB) is more attractive because of its excellent electrical property, chemical stability and low production cost. However, normal CB has a low capacitance, resulting in the occurrence of power overshoot with unstable power output [9]. It has been reported that the enhancement of capacitance can be achieved by surface chemical activation [14-18] or the

\footnotetext{
* Corresponding author. Tel: +86-22-87897992; Fax: +86-22-87897993; E-mail: pxinhong@126.com This work was supported by the National Natural Science Foundation of China (NSFC, 51409052) and the Scholarship for Excellent PhD Student from Shanghai Tongji Gao Tingyao Environmental Science \& Technology Development Foundation (STGEF). 
addition of metal oxides (eg. $\mathrm{Fe}_{3} \mathrm{O}_{4}$ ) [19]. Here, we used $\mathrm{CB}$ as the matrix for the electrode active material. To further increase the capacitance of the $\mathrm{CB}$ anode to achieve overshoot elimination, chemical activation with $\mathrm{HNO}_{3}$ and $\mathrm{KOH}$ at low temperature was employed (denoted as CBN and CBK, respectively). Subsequently, $\mathrm{Fe}_{3} \mathrm{O}_{4}$ was added to the host with a content of 5 wt.\% for the untreated and treated CB anodes (denoted hereafter as $\mathrm{CBFe}, \mathrm{CBNFe}$ and $\mathrm{CBKFe}$ ). The electricity-generating behavior of the chemically modified $\mathrm{CB}$ as the MFC anode was evaluated and compared with a CB anode as the control. The effects of structure and texture on the physical characteristics and electrochemical capacitance were discussed.

\section{Experimental}

\subsection{Surface chemical activations of $C B$}

$\mathrm{KOH}$ and $\mathrm{HNO}_{3}$ were individually utilized for the pretreatment of CB ( $\mathrm{T}_{90}$, Tianjin Jinqiushi Chemical Co. Ltd, China). First, the CB powder (1.0 g) was dispersed in KOH-ethanol solution (5.0 $\mathrm{g} \mathrm{KOH}$ dissolved in $40 \mathrm{~mL}$ ethanol) or concentrated $\mathrm{HNO}_{3}$ (14 mol/L, $100 \mathrm{~mL}$ ) and treated ultrasonically for $0.5 \mathrm{~h}$, and then continuously stirred for $24 \mathrm{~h}$ at $80^{\circ} \mathrm{C}$. After cooling to room temperature, the activated powder was soaked in $\mathrm{HCl}$ or $\mathrm{NaOH}$ solution ( $1 \mathrm{~mol} / \mathrm{L}$ ) for $24 \mathrm{~h}$, and then rinsed with distilled water using a suction filter to remove residual alkaline or acid. Finally, the product was dried overnight in a vacuum oven at $60^{\circ} \mathrm{C}$.

\subsection{Assembly of the MFC}

$\mathrm{Fe}_{3} \mathrm{O}_{4}$ was prepared by the co-precipitation method according to reported details [20]. The sheet comprising the electrode matrix and polytetrafluoroethylene (PTFE, $60 \mathrm{wt} \%$; Horizon LID, Shanghai, China) emulsion with the ratio of 19:1 was roll-pressed onto the current collector of an SSM (type 304L, 80 $\times 80$ mesh, thickness of $0.2 \mathrm{~mm}$, Hebei Anping County Shengze Screen Co. Ltd, China). This was used as the MFC anode. The detailed process was described elsewhere [21]. A cathode with a sandwich structure was made with a Pt/C catalytic layer $[0.5$ $\mathrm{mg} / \mathrm{cm}^{2}$ ), carbon fiber mesh (10 wt.\% wet proof, Jilin Carbon Plant Co. Ltd, China) base layer and four PTFE diffusion layer faced to air as shown previously [22].

The cube shaped membrane-less MFC was a $28 \mathrm{~mL}$ cylindrical chamber $\left(4 \mathrm{~cm}\right.$ long by $3 \mathrm{~cm}$ diameter; $7 \mathrm{~cm}^{2}$ project area; electrode spacing of $4 \mathrm{~cm}$ ). It was run in batch mode at 30 $\pm 1{ }^{\circ} \mathrm{C}$ in a controlled biochemical incubator (SPX150BIII, Tianjin Taisite Co. Ltd, China) under $1 \mathrm{k} \Omega$ except when stated otherwise. All the anodes were inoculated and pre-acclimated with the effluent from other parent MFCs that had been running for one year. The anode medium was the same as the prevous study with an initial COD $780 \mathrm{mg} / \mathrm{L}$, which was replenished when the cell voltage $\leq 20 \mathrm{mV}$. Trace minerals $(12.5 \mathrm{~mL} / \mathrm{L})$ and vitamins ( $5 \mathrm{~mL} / \mathrm{L}$ ) were added, and the $\mathrm{pH}$ was adjusted to 7.0 with $50 \mathrm{mmol}$ phosphate buffer solution (PBS; $\mathrm{Na}_{2} \mathrm{HPO}_{4}, 4.09$ $\left.\mathrm{g} / \mathrm{L} ; \mathrm{NaH}_{2} \mathrm{PO}_{4} \cdot \mathrm{H}_{2} \mathrm{O}, 2.93 \mathrm{~g} / \mathrm{L} ; \mathrm{KCl}, 0.13 \mathrm{~g} / \mathrm{L} ; \mathrm{NH}_{4} \mathrm{Cl}, 0.31 \mathrm{~g} / \mathrm{L}\right)$ [23] when the output voltages were $\geq 500 \mathrm{mV}$ during four con- secutive periods, marked as $1 \mathrm{st}, 2 \mathrm{nd}, 3 \mathrm{rd}$, 4th cycle, respectively.

\subsection{Physical and electrochemical characterization}

The surface functional groups were observed with Fourier Transform Infrared spectroscopy (FTIR, KBr pellet, $4000 \sim 400$ $\mathrm{cm}^{-1}$ ) using a Magna560 (Thereto Nicolet Co. Ltd., USA) apparatus. The element mapping of the sample surface was performed by energy dispersive X-ray spectroscopy (EDX, Nova NanoSEM 430, FEI Company, USA). The specific surface area ( $\left.S_{\mathrm{BET}}\right)$ and pore size distribution (PSD) were calculated by the Brunauer-Emmett-Teller (BET) and Barret-Joyner-Halenda (BJH) equations. The total pore volume ( $\left.V_{\text {total }}\right)$ was obtained from the $\mathrm{N}_{2}$ adsorption isotherm at $p / p_{0}=0.99$, and the micropore surface area $\left(S_{\text {micro }}\right)$ and micropore volume $\left(V_{\text {micro }}\right)$ were extracted by the $t$-plot method [24]. These analyses were carried out by a TriStar 3000 (Micromeritics, ASAP2020, USA) at $-196{ }^{\circ} \mathrm{C}$ with $\mathrm{N}_{2}$ as adsorbate. The sample surface $\mathrm{pH}$ was determined by soaking $0.45 \mathrm{~g}$ of dried CB powder in $20 \mathrm{~mL}$ deioned water and vigorously magnetically stirred for $18 \mathrm{~h}$. The pH (S20P, SevenEasy Plus, Mettler Toledo, Switzerland) of the filtrate was referred to as the $\mathrm{pH}$ of the $\mathrm{CB}$ sample for simplication [25]. The apparent contact angle was measured using a 1 mL of distilled water drop and a Harke-SPCA (Beijing Hake Co. Ltd, China) apparatus to characterize the surface wettability of the electrode. The scanning electron microscope (SEM) images of the microbe on the MFC anode were obtained using a Shimadzu SS-550 operated at $15.0 \mathrm{kV}$.

The voltage across the resistor was monitored at $30 \mathrm{~min}$ intervals using a date acquisition system (PISO-813, ICP DAS Co., Ltd.). The polarization and power density curves were acquired by varying the external resistance from 1000 to $10 \Omega$ at a time interval of $30 \mathrm{~min}$. Before and after bacteria inoculation, the capacitance determination of the MFC anode was peformed by a cyclic voltammetry (CV) scan recorded from $-0.8-0 \mathrm{~V}$ (vs. $\mathrm{Ag} / \mathrm{AgCl}$ ) at a rate of $0.1 \mathrm{mV} / \mathrm{s}$ using a CHI660D potentiostat (CH Instruments Inc., China). The abiotic anode was soaked in $50 \mathrm{mmol} / \mathrm{L}$ PBS in the MFC reactor for $48 \mathrm{~h}$ before the CV test. All the electrochemical measurements were performed with the anode serving as the working electrode, the air-cathode as the counter electrode and an $\mathrm{Ag} / \mathrm{AgCl}$ electrode close to the anode as the reference electrode $(+197 \mathrm{mV}, 3.5 \mathrm{~mol} / \mathrm{L} \mathrm{KCl}$, vs. SHE).

\section{Results and discussion}

\subsection{Power production behavior in MFCs}

The tests of electrode potential and power density curves were started in Cycle 2 (Fig. 1(a)). The CB anode gave a MPD of $821 \pm 2 \mathrm{~mW} / \mathrm{m}^{2}$ at a current density (i) of $2.42 \mathrm{~A} / \mathrm{m}^{2}$ with subsequent current-fluctuation which first increased to $2.68 \mathrm{~A} / \mathrm{m}^{2}$ $(150 \Omega)$, then returned to $1.98 \mathrm{~A} / \mathrm{m}^{2}(50 \Omega)$, and then recovered to $2.12 \mathrm{~A} / \mathrm{m}^{2}(10 \Omega)$. After chemical activation, the MPDs of the CBN and CBK anodes were unexpectedly decreased by $2.4 \%$ and $1.1 \%$ to $801 \pm 5 \mathrm{~mW} / \mathrm{m}^{2}$ at $i=2.76 \mathrm{~A} / \mathrm{m}^{2}$ and $812 \pm 13$ 

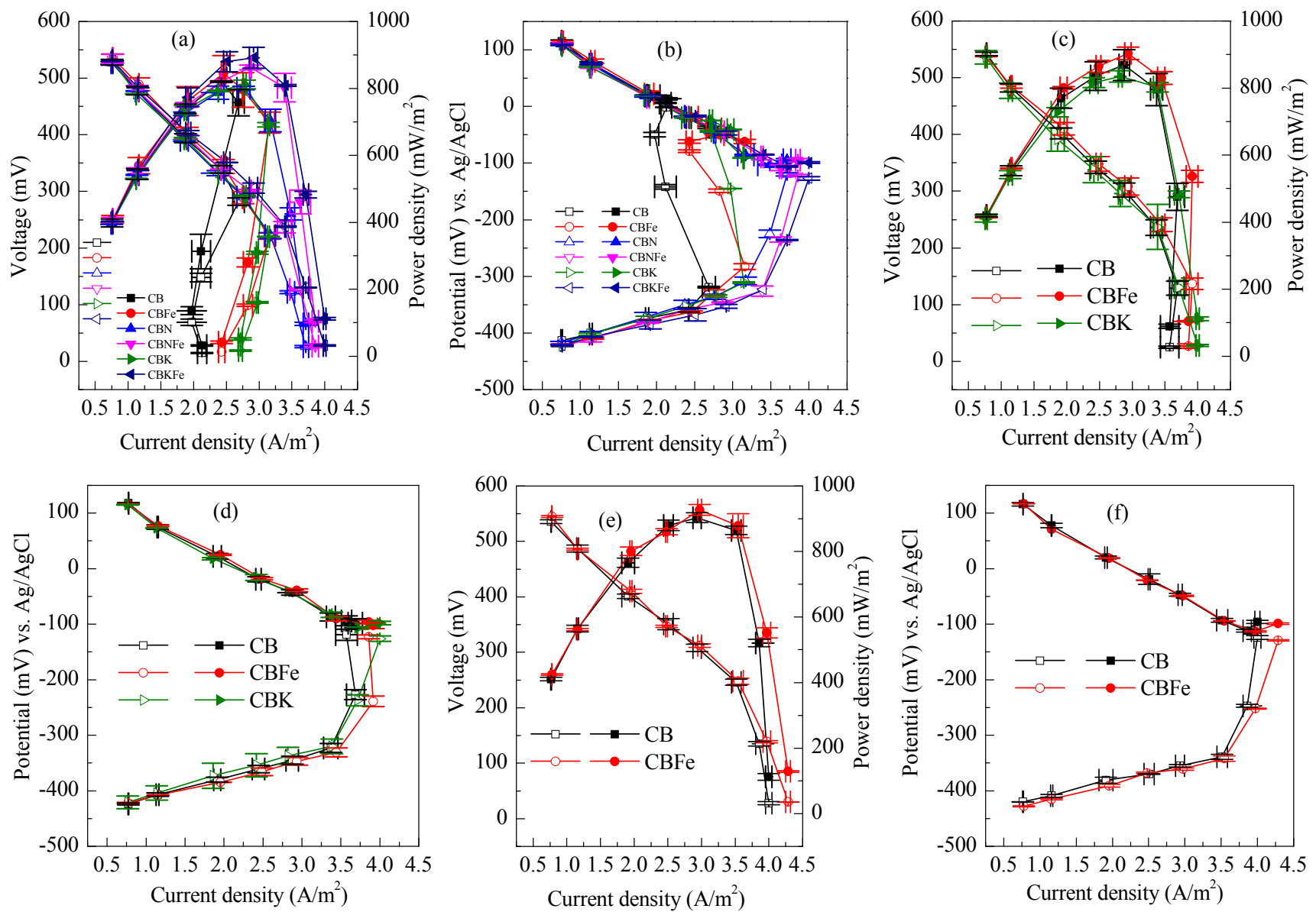

Fig. 1. Power density curves ((a), (c), (e) and electrode potential curves ((b), (d), (f), open symbols represent anode potential, closed symbols are cathode potential) of the MFCs in Cycle 2, 3 and 4. Error bars $\pm \mathrm{SD}$ are based on averages measured in duplicate. (CB: carbon black; $\mathrm{CBFe} \mathrm{Fe}_{3} \mathrm{O}_{4}$-added CB; $\mathrm{CBN}$ : $\mathrm{HNO}_{3}$-treated CB; $\mathrm{CBNFe}: \mathrm{Fe}_{3} \mathrm{O}_{4}$-added $\mathrm{CBN}$; $\mathrm{CBK}$ : $\mathrm{KOH}$-treated $\mathrm{CB}$; $\mathrm{CBKFe}$ : $\mathrm{Fe}_{3} \mathrm{O}_{4}$-added $\mathrm{CBK}$ ).

$\mathrm{mW} / \mathrm{m}^{2}$ at $i=2.78 \mathrm{~A} / \mathrm{m}^{2}$, respectively. Interestingly, the MPDs of the $\mathrm{Fe}_{3} \mathrm{O}_{4}$-added $\mathrm{MFC}$ were $3.0 \%, 7.7 \%$ and $9.7 \%$ higher than those of those without added $\mathrm{Fe}_{3} \mathrm{O}_{4}$ with the values of $845 \pm 52$ $\mathrm{mW} / \mathrm{m}^{2}$ at $2.45 \mathrm{~A} / \mathrm{m}^{2}$ for CBFe-MFC (CBNFe-MFC: $863 \pm 7$ $\mathrm{mW} / \mathrm{m}^{2}$ at $2.85 \mathrm{~A} / \mathrm{m}^{2}$; CBKFe-MFC: $891 \pm 31 \mathrm{~mW} / \mathrm{m}^{2}$ at 2.91 $\mathrm{A} / \mathrm{m}^{2}$ ). Different from CBN, CBNFe and CBKFe that did not show overshoot, there was a current overshoot in CBK-MFC when the resistance was switched from 1000 to $50 \Omega$, and a rapid sharp drop of current density for CBFe appeared when the external resistance was varied from 100 to $50 \Omega$. The electrode potential curves indicated that the overshoot was from the anodes but not the cathodes, as all the MFCs cathodes maintained similar working potentials (Fig. 1(b)). The abnormal rapid increases in anode potential of CBK and CBFe were observed from -311 to $-44 \mathrm{mV}$ and -283 to $-49 \mathrm{mV}$ (vs. $\mathrm{Ag} / \mathrm{AgCl}$ ), while the $\mathrm{CB}$ anode potential appeared as a current hysteresis over the potential window of -319 to $-50 \mathrm{mV}$ (vs. $\mathrm{Ag} / \mathrm{AgCl}$ ) [12].

In the following Cycle 3 (Fig. 1(c)), the MPD of CBK-MFC had a $2.7 \%$ increase of $834 \pm 31 \mathrm{~mW} / \mathrm{m}^{2}$ at a $1.1 \%$ increase of $i$ $\left(2.81 \mathrm{~A} / \mathrm{m}^{2}\right)$ with overshoot eliminationg. This was possibly due to the maturation of the anodic biofilm, which implied the successful startup of CBK-MFC as discussed previously [9]. However, the overshoot still existed with the MPDs and in- creased by $5.7 \%$ and $6.9 \%$ to $868 \pm 45 \mathrm{~mW} / \mathrm{m}^{2}\left(2.87 \mathrm{~A} / \mathrm{m}^{2}\right)$ for CB-MFC and $903 \pm 18 \mathrm{~mW} / \mathrm{m}^{2}\left(2.93 \mathrm{~A} / \mathrm{m}^{2}\right)$ for CBFe-MFC. The abnormal increase of the anode potential became smooth for

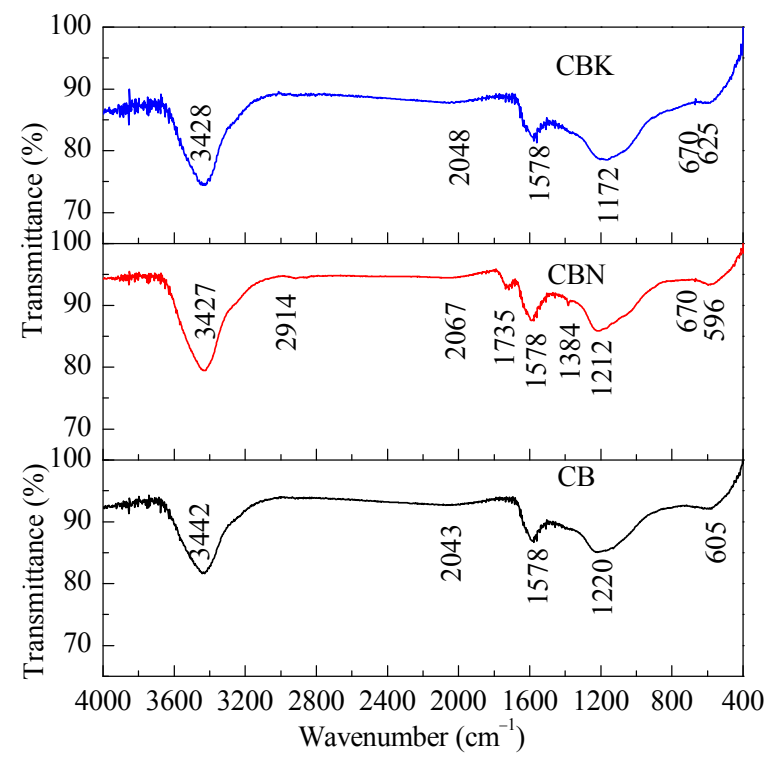

Fig. 2. FTIR spectra of carbon black before and after chemical activation. 
Table 1

EDX analysis of carbon black before and after chemical activation.

\begin{tabular}{lccc}
\hline Sample & CB & CBN & CBK \\
\hline$w(\mathrm{C}) / \%$ & 95.21 & 86.47 & 89.67 \\
$w(\mathrm{O}) / \%$ & 4.41 & 13.05 & 9.83 \\
$w(\mathrm{~S}) / \%$ & 0.38 & 0.09 & 0.14 \\
$w(\mathrm{~N}) / \%$ & - & 0.39 & - \\
$w(\mathrm{~K}) / \%$ & - & - & 0.36 \\
\hline
\end{tabular}

CB and CBFe (Fig. 1(d)). Notably, the overshoot disappeared for both CB-MFC and CBFe-MFC in Cycle 4, and there was a $10 \%$ increase in the MPD to $903 \pm 15 \mathrm{~mW} / \mathrm{m}^{2}\left(2.93 \mathrm{~A} / \mathrm{m}^{2}\right)$ for $\mathrm{CB}$ and $927 \pm 15 \mathrm{~mW} / \mathrm{m}^{2}\left(2.97 \mathrm{~A} / \mathrm{m}^{2}\right)$ for CBFe (Fig. 1(e)). These values were in accordance with the changes of the anode potential curve (Fig. 1(f)).

\subsection{Textural and surface chemistry properties}

For each CB sample, a broad FTIR absorption band at $3500-3100 \mathrm{~cm}^{-1}$ was ascribed to the stretching vibration of an $\mathrm{OH}$ group. The band at 2067-2043 $\mathrm{cm}^{-1}$ corresponded to $\mathrm{C}=0$ vibrations (Fig. 2). After activation treatment, the peak appearing at $670 \mathrm{~cm}^{-1}$ was attributed to the bending vibration of $\mathrm{O}-\mathrm{H}$, which demonstrated that the intensity associated with the $\mathrm{OH}$ group was strongly increased. As expected, there was a new peak at $1384 \mathrm{~cm}^{-1}$ for CBN which displayed a characteristic sharp absorption band of the asymmetric stretch of $\mathrm{NO}_{3}{ }^{-}$. There was another new stretching vibration peak of $\mathrm{C}-\mathrm{O}$ at $1172 \mathrm{~cm}^{-1}$ for CBK. The EDX analysis showed the presence of $\mathrm{C}(0.28 \mathrm{keV})$, $\mathrm{O}(0.52 \mathrm{keV}), \mathrm{S}$ (2.3 keV) atoms in each CB sample. However, it was noticed that there was an increase in the oxygen content and a decrease in the percentage of carbon after chemical activation comparing with the control (Table 1). The existence of $\mathrm{N}$ $(0.39 \mathrm{keV})$ demonstrated that the nitrogen-associated functionality was anchored on the surface after $\mathrm{HNO}_{3}$ activation. The $\mathrm{K}$ signal ( $3.31 \mathrm{keV}$ ) was due to adsorbed potassium from $\mathrm{KOH}$ activation. The FTIR and EDX analyses confirmed that the oxygen (nitrogen)-containing functionalities were introduced to the activated CB surface by the chemical treatment, which would make more active sites to improve the electrochemical response and wettability of the MFC anode.

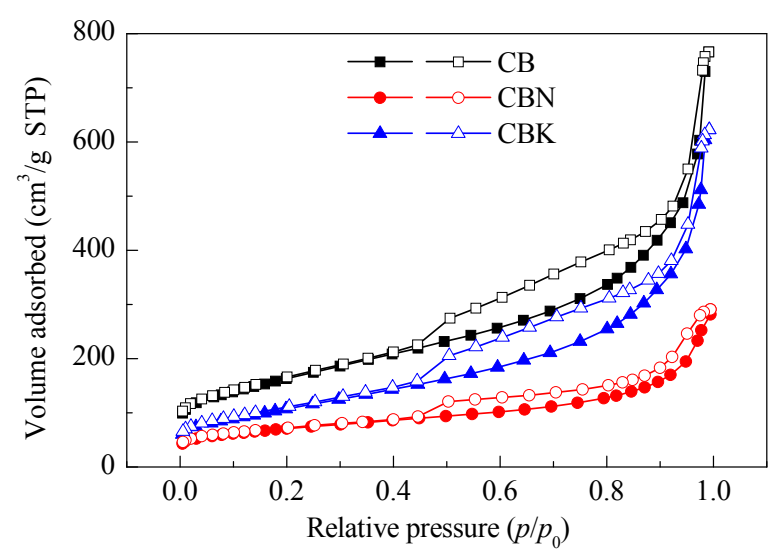

Fig. 3. $\mathrm{N}_{2}$ adsorption/desorption analysis of carbon black before and after chemical activations (solid: adsorption, hollow: desorption).
Table 2

Porosity characteristics of the carbon black before and after chemical activation.

\begin{tabular}{lccc}
\hline Sample & CB & CBN & CBK \\
\hline$S_{\text {BET }}\left(\mathrm{cm}^{2} / \mathrm{g}\right)$ & 585.8 & 251.2 & 424.9 \\
$S_{\text {micro }}\left(\mathrm{cm}^{2} / \mathrm{g}\right)$ & 37.1 & 48.6 & 36.0 \\
$S_{\text {meso }}\left(\mathrm{cm}^{2} / \mathrm{g}\right)$ & 548.7 & 202.6 & 388.9 \\
$V_{\text {total }}\left(\mathrm{cm}^{3} / \mathrm{g}\right)$ & 0.89 & 0.36 & 0.75 \\
$V_{\text {micro }}\left(\mathrm{cm}^{3} / \mathrm{g}\right)$ & 0.01 & 0.02 & 0.02 \\
$V_{\text {meso }}\left(\mathrm{cm}^{3} / \mathrm{g}\right)$ & 0.88 & 0.34 & 0.73 \\
$V_{\text {micro }} / V_{\text {exter }}$ & 1.0 & 6.0 & 3.0 \\
$D^{\text {a }} / \mathrm{nm}$ & 6.1 & 5.7 & 7.7 \\
\hline
\end{tabular}

${ }^{a}$ Average pore diameter.

According to the IUPAC classification, the $\mathrm{N}_{2}$ adsorption isotherms for each CB sample were Type IV with a Type H3 hysteresis loop as noted in Fig. 3. In the range of $p / p_{0}>0.95$, the slope of the hysteresis loops followed the order of CBK > CB $>$ CBN, which were related to the pore width $(D, 4 \mathrm{~V} / \mathrm{S}$ by BET) as listed in Table 2 . Both $S_{\text {BET }}\left(585.8 \mathrm{~cm}^{2} / \mathrm{g}\right)$ and $V_{\text {total }}(0.89$ $\mathrm{cm}^{3} / \mathrm{g}$ ) of CB were decreased by $57 \%$ and $60 \%$ to $251.2 \mathrm{~cm}^{2} / \mathrm{g}$ and $0.36 \mathrm{~cm}^{3} / \mathrm{g}$ after the acid treatment. There was a similar reduction of $28 \%$ (424.9 $\left.\mathrm{cm}^{2} / \mathrm{g}\right)$ and $16 \%\left(0.75 \mathrm{~cm}^{3} / \mathrm{g}\right)$ after the alkaline treatment, which may have resulted from hole wall collapse and aperture blockage caused by the functional groups from the chemical activation as discussed by Chen et al. [26]. It should be noted that there were obvious changes in the PSD for the activated CB matrix as presented in Table 2. The $S_{\text {micro }}$ increased by $29.7 \%$ to $48.6 \mathrm{~cm}^{2} / \mathrm{g}$ for the $\mathrm{HNO}_{3}$ activation $\mathrm{CB}$, while it was slightly decreased by $2.7 \%$ to $36.0 \mathrm{~cm}^{2} / \mathrm{g}$ for the KOH activation CB. Meanwhile, the $S_{\text {meso }}$ decreased by $63 \%$ for the acidic pretreated $\mathrm{CB}\left(\mathrm{CBN}, 202.6 \mathrm{~cm}^{2} / \mathrm{g}\right.$ ) and $29 \%$ for the alkaline pretreated CB (CBK, $388.9 \mathrm{~cm}^{2} / \mathrm{g}$ ). In particular, the

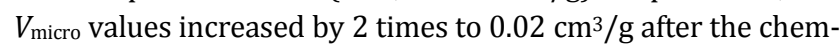
ical treatment, while the $V_{\text {meso }}$ values decreased by $63 \%$ to 0.34 $\mathrm{cm}^{3} / \mathrm{g}$ for CBN and $18 \%$ to $0.73 \mathrm{~cm}^{3} / \mathrm{g}$ for CBK. The higher microporosity contributed to the electrochemically accessible surface area [27], which was verified by the following capacitance behavior analysis.

Table 3 showed that the $\mathrm{pH}$ of $\mathrm{CB}(6.30)$ was close to that of deionized water (6.29). After acid treatment, the $\mathrm{pH}$ value slightly decreased by $2.2 \%$ to 6.16 , while the $\mathrm{pH}$ increased by $11 \%$ to 7.11 after alkaline treatment. The variation of the $\mathrm{pH}$ can be ascribed to the adsorption of soluble reagents in the micropores and mesopores of the CB matrixes. The wettability of an electrode surface is routinely elucidated by its water contact angle. The value $\left(94.7^{\circ}\right)$ of the contact angle of the CB anode was higher than $90^{\circ}$ as shown in Table 3, suggesting the hydrophobicity characteristics of its surface. This was attributed to its non-polar structure. The $\mathrm{KOH}$ activated $\mathrm{CB}$ anode displayed a lower contact angle with the value of $62.7^{\circ}$, and the lowest contact angle of $56.9^{\circ}$ was found with the $\mathrm{HNO}_{3}$ activat-

\section{Table 3}

The comparisons of surface $\mathrm{pH}$ and contact angle of carbon black before and after chemical activations. (DI: deioned water).

\begin{tabular}{lcccc}
\hline Sample & DI & CB & CBN & CBK \\
\hline pH & 6.29 & 6.30 & 6.16 & 7.11 \\
Contact angle $\left({ }^{\circ}\right)$ & - & 94.7 & 56.9 & 62.7 \\
\hline
\end{tabular}




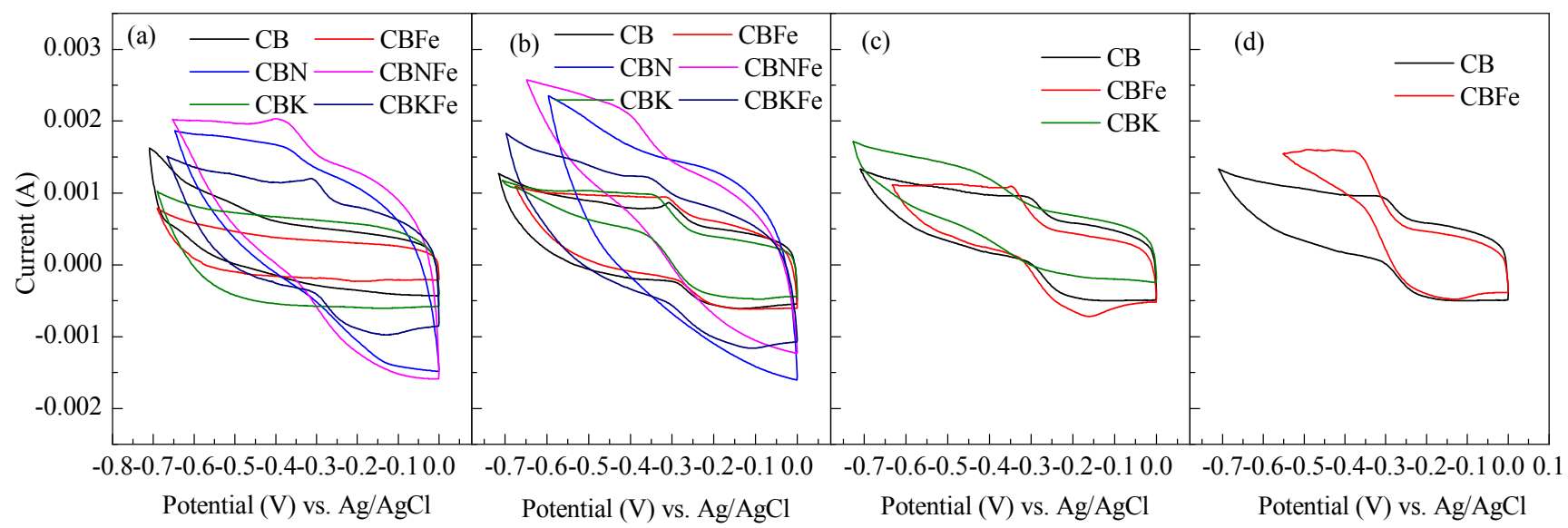

Fig. 4. CVs of each CB anode before and after the exoelectrogenic bacterial adherence. (a) CVs of abiotic anodes; (b) CVs of biotic anodes in Cycle 2; (c) CVs of biotic anodes in Cycle 3; (d) CVs of biotic anodes in Cycle 4.

ed CB anode, indicating that surface hydrophiliciy was increased by the activation treatment, which was conducive for ion adsorption on the surface and bacterial adhesion in the MFC anode.

\subsection{Electrochemical behavior of the MFC anode}

Electrochemical studies of the CB anodes were conducted using the specific capacitance $\left(C_{\mathrm{m}}, \mathrm{F} / \mathrm{cm}^{2}\right)$ before and after the bacteria colonization, which was calculated by

$$
C_{\mathrm{m}}=I t / A \Delta E
$$

where $I(A)$ is the the charge-discharge current of the CV record, $t(\mathrm{~s})$ is the time of CV scan, $A\left(7 \mathrm{~cm}^{2}\right)$ is the projection area of the electrode, and $\Delta E(\mathrm{~V})$ is the operating potential window (Fig. 4).

It was found that the acid-pretreated $\mathrm{CB}(\mathrm{CBN})$ had the maximum abiotic capacitance $\left(C_{\mathrm{m}}\right.$ abiotic $)$ of $1.52 \mathrm{~F} / \mathrm{cm}^{2}$, with a value $46 \%$ and $53 \%$ higher than those of the alkaline-pretreated $\mathrm{CB}\left(\mathrm{CBK}, 0.81 \mathrm{~F} / \mathrm{cm}^{2}\right)$ and untreated control ( $\mathrm{CB}, 0.71 \mathrm{~F} / \mathrm{cm}^{2}$ ). As we know, the micropores play a crucial role in ion accumulation and enhancing the electrical double layer [27]. It has been reported that micropores can be created by a heating treatment with $\mathrm{KOH}$ at $800{ }^{\circ} \mathrm{C}$ in argon atmosphere [28] or $\mathrm{HNO}_{3}$ oxidation at $120{ }^{\circ} \mathrm{C}$ [29]. As shown in Table 2, there were obvious increases of 2 times in the volume of the micropores for the activated CB. The acid-pretreated CB exhibited a superior capacitance characteristic compared to the alkaline-pretreated CB due to its good electrolyte affinity, which can be explained by the contact angle measurement [30]. This was also shown by the FTIR results that the oxygen (nitrogen)-containing functional groups improved the surface hydrophilicity of $\mathrm{HNO}_{3}$-activated $\mathrm{CB}$ anode. Different from Deeke's report [31], the improvement of abiotic capacitance did not have a positive effect on the power output of the MFC after chemical activation with $\mathrm{HNO}_{3}$ and $\mathrm{KOH}$, which probably resulted from the decrease of actual contact area between the bacteria and the electrode [32] as shown by the reduction of the specific surface area following the order of $\mathrm{CB}>\mathrm{CBK}>\mathrm{CBN}$. Thus it was inferred that the surface area of the electrode material plays a key role in the capacitance performance. This will need to be addressed in future. Furthermore, it was found that the $C_{\mathrm{m}}$ abiotic of $\mathrm{Fe}_{3} \mathrm{O}_{4}$-added anodes was higher than those of $\mathrm{Fe}_{3} \mathrm{O}_{4}$-unadded ones as shown in Table 3 . This was in fair agreement with the report that $\mathrm{Fe}_{3} \mathrm{O}_{4}$ can deliver remarkable pseudo-capacitive activity [33].

With the enrichment of anodic bacteria, the biotic $\mathrm{CV}$ was performed with the cell voltage $\leq 20 \mathrm{mV}$. $C_{\mathrm{m}}$ for CBN (CBNFe and CBKFe) increased to 1.76 (1.84 and 1.26) F/cm² in Cycle 2. For $\mathrm{CBK}, C_{\mathrm{m}}$ increased from $0.9 \mathrm{~F} / \mathrm{cm}^{2}$ in Cycle 2 to $1.1 \mathrm{~F} / \mathrm{cm}^{2}$ in Cycle 3. $C_{\mathrm{m}}$ of $\mathrm{CB}(\mathrm{CBFe})$ was consecutively increased from 0.79 (0.82) F/ $\mathrm{cm}^{2}$ (Cycle 2) to 0.86 (0.9) F/ $\mathrm{cm}^{2}$ (Cycle 3) and then to 1.12 (1.17) $\mathrm{F} / \mathrm{cm}^{2}$ (Cycle 4). It was clear that the biotic capacitance $\left(C_{\mathrm{m}}\right.$ biotic $)$ was increased with the values of $0.12-0.4 \mathrm{~F} / \mathrm{cm}^{2}$ by different degrees, indicating that the living microorganisms
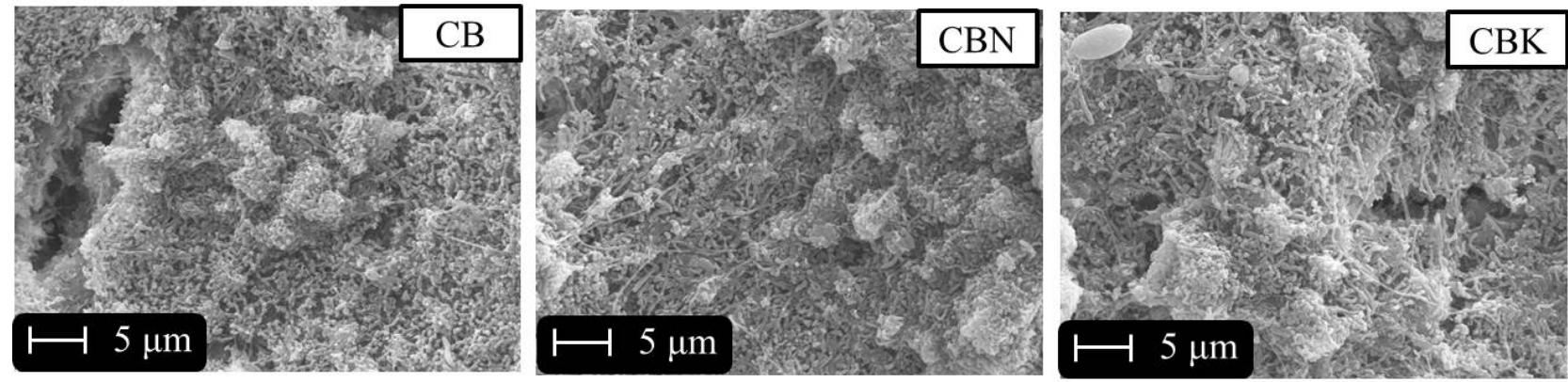

Fig. 5. SEM images with $2 \mathrm{~K}$ magnification of the anodes with the exoelectrogenic bacterial adherence before and after chemical activations. 
Table 4

Capacitance of $\mathrm{CB}$ anode before and after chemical modification based on CV analysis (2c, 3c and 4c represented Cycle 2, 3 and 4 individually).

\begin{tabular}{lcccc}
\hline Anode & $\begin{array}{c}C_{\mathrm{m}}^{\text {abiotic }} \\
\left(\mathrm{F} / \mathrm{cm}^{2}\right)\end{array}$ & $\begin{array}{c}C_{\mathrm{m}} \text { biotic:2c } \\
\left(\mathrm{F} / \mathrm{cm}^{2}\right)\end{array}$ & $\begin{array}{c}C_{\mathrm{m}}^{\text {biotic·3c }} \\
\left(\mathrm{F} / \mathrm{cm}^{2}\right)\end{array}$ & $\begin{array}{c}C_{\mathrm{m}} \text { biotic·4c } \\
\left(\mathrm{F} / \mathrm{cm}^{2}\right)\end{array}$ \\
\hline $\mathrm{CB}$ & 0.71 & 0.79 & 0.86 & 1.12 \\
$\mathrm{CBFe}$ & 0.77 & 0.82 & 0.9 & 1.17 \\
$\mathrm{CBN}$ & 1.52 & 1.76 & - & - \\
$\mathrm{CBNFe}$ & 1.77 & 1.84 & - & - \\
$\mathrm{CBK}$ & 0.81 & 0.9 & 1.1 & - \\
$\mathrm{CBKFe}$ & 1.14 & 1.26 & - & - \\
\hline
\end{tabular}

accelerated ion transport from the electrolytic solution to the electrode between each CB particle and bacterial conductive appendage. This would be due to the transient charge storage of oxidoreductase on the cell membrane and in the cytoplasm [34]. SEM pictures suggested the crosslinking among the indigenous microorganisms. However, there was no significant difference in morphology and amount of bacterial cells (Fig. 5). Associating the anodic capacitance with the current overshoot, it can be found that the higher $C_{\mathrm{m}}$ of the MFC anode gave the better alleviation of the current return. Our previous research provided the proof-of-concept that a steady state was achieved with a concomitant elimination of MFC overshoot [9]. This was shown by the power density curves as plotted in Fig. 1. So, we can interpret this result as evidence that, either from the physical property of the electrode matrix or the capacitance compensation of the anodic biofilm, the system using CB as the MFC anode can be considered to be stabilized so long as the anodic capacitance is no less than $1.1 \mathrm{~F} / \mathrm{cm}^{2}$.

\section{Conclusions}

This study investigated the power generating behavior of MFCs using chemically modified $\mathrm{CB}$ as the MFC anode. The steady power output obtained followed the order of CBN > CBK $>$ CB. This was due to the improved anodic capacitance for electron transfer from the surface modification. Electrochemi- cal analysis revealed that the chemically modified CB anode exhibited favorable power stability, and can therefore be recommended for use as the MFC anode.

\section{Acknowledgments}

Thanks go to Associate Prof. Xin Wang of Nankai University, Tianjin for his kind help. The authors thank the anonymous reviewers for their instructive comments.

\section{References}

[1] Lü Z S, Xie D H, Li F S, Hu Y, Wei C H, Feng C H. J Power Sources, 2014, 246: 642

[2] Wang H M, Ren Z J. Biotechnol Adv, 2013, 31: 1796

[3] Feng C H, Li F B, Sun K W, Liu Y Y, Liu L, Yue X J, Tong H. Bioresour Technol, 2011, 102: 1131

[4] Kelly P T, He Z. Bioresour Technol, 2014, 153: 351

[5] Huang L P, Yao B L, Wu D, Quan X.J Power Sources, 2014, 259: 54

[6] Rozendal R A, Leone E, Keller J, Rabaey K. Electrochem Commun, 2009, 11: 1752

[7] Kim B H, Chang I S, Gil G C, Park H S, Kim H J. Biotechnol. Lett., 2003, 25: 541

[8] Chen S S, Liu G Z, Zhang R D, Qin B Y, Luo Y. Environ Sci Technol, 2012, 46: 2467

[9] Peng X H, Yu H, Yu H B, Wang X. Bioresour Technol, 2013, 138: 353

[10] Hong Y Y, Call D F, Werner C M, Logan B E. Biosen Bioelectron, 2011, 28: 71

[11] Watson V J, Logan B E. Electrochem Commun, 2011, 13: 54

[12] Ieropoulos I, Winfield J, Greenman J. Bioresour Technol, 2010, 101: 3520

[13] Winfield J, Ieropoulos I, Greenman J, Dennis J. Bioelectrochemistry, 2011, 81: 22

[14] Huang W, Zhang Y M, Bao S X, Cruz R, Song S X. Desalination, 2014, 340: 67

[15] Kikuchi K, Yasue T, Yamashita R, Sakuragawa S, Sudoh M, Itagaki M. Electrochemistry, 2013, 81: 828

[16] Carriazo D, Gutiérrez M C, Picó F, Rojo J M, Fierro J L G, Ferrer M L, del Monte F. ChemSusChem, 2012, 5: 1405

\section{Graphical Abstract}

Chin. J. Catal., 2015, 36: 1326-1332 doi: 10.1016/S1872-2067(15)60880-4

\section{Bioelectricity-generating behavior of a chemically modified carbon black anode in microbial fuel cells}

Xinhong Peng*, Xizhang Chu, Wei Liu, Shenghui Wang, Yi Zou, Xiaonan Wang

Institute of Seawater Desalination and Multipurpose Utilization, State Oceanic Administration

The introduction of oxygen(nitrogen)-containing functional groups enhanced the anodic capacitance and improved the power stability of microbial fuel cells.

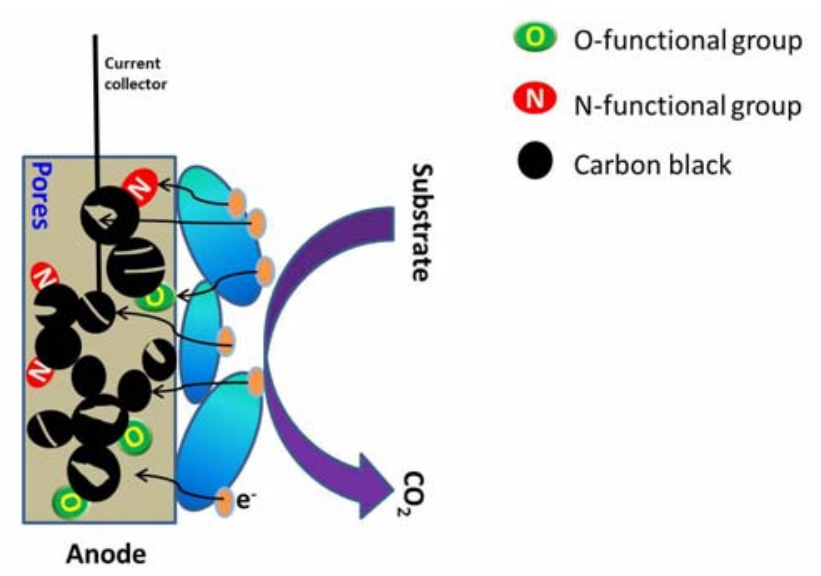


[17] Kaludjerović B V, Jovanović V M, Stevanović S I, Bogdanov Ž D. Ultrason Sonochem, 2014, 21: 782

[18] Duteanu N, Erable B, Kumar S M S, Ghangrekar M M, Scott K. Bioresour Technol, 2010, 101: 5250

[19] Shi W H, Zhu J X, Sim D H, Tay Y Y, Lu Z Y, Zhang X J, Sharma Y, Srinivasan M, Zhang H, Hng H H, Yan Q Y. J Mater Chem, 2011, 21: 3422

[20] Peng X H, Yu H B, Wang X, Zhou Q X, Zhang S J, Geng L J, Sun J W, Cai Z. Bioresour Technol, 2012, 121: 450

[21] Peng X H, Yu H B, Wang X, Gao N, Geng L J, Ai L N. J Power Sources, 2013, 223: 94

[22] Jin T, Zhou L, Luo J M, Yang J, Zhao Y Y, Zhou M H. J Chem Technol Biotechnol, 2013, 88: 2075

[23] Wang X, Cheng S A, Feng Y J, Merrill M D, Saito T, Logan B E. Environ Sci Technol, 2009, 43: 6870

[24] Pognon G, Brousse T, Bélanger D. Carbon, 2011, 49: 1340

[25] Yan R, Chin T, Ng Y L, Duan H Q Liang D T, Tay J H. Environ Sci
Technol, 2004, 38: 316

[26] Chen Z H, Li K X, Zhang P, Pu L T, Zhang X, Fu Z. Chem Eng J, 2015, 259: 820

[27] Xu F, Cai R J, Zeng Q C, Zou C, Wu D C, Li F, Lu X E, Liang Y R, Fu R W.J Mater Chem, 2011, 21: 1970

[28] Kierzek K, Frackowiak E, Lota G, Gryglewicz G, Machnikowski J. Electrochim Acta, 2004, 49: 515

[29] Dinh T M, Pech D, Brunet M, Achour A.J Phys: Conference Series, 2013, 476: 012106/1

[30] Yoo H, Min M, Bak S, Yoon Y, Lee H.J Mater Chem A, 2014, 2: 6663

[31] Deeke A, Sleutels T H J A, Hamelers H V M, Buisman C J N. Environ Sci Technol, 2012, 46: 3554

[32] Kano T, Suito E, Hishida K, Miki N. Jpn J Appl Phys, 2012, 51: 06FK04

[33] Liu M M, Sun J.J Mater Chem A, 2014, 2: 12068

[34] Schrott G D, Bonanni P S, Robuschi L, Esteve-Nunez A, Busalmen J P. Electrochim Acta, 2011, 56: 10791

\title{
化学修饰炭黑在微生物燃料电池中的生物产电行为
}

\author{
彭新红 ${ }^{*}$, 初喜章, 刘 玮, 王生辉, 邹一, 王晓楠 \\ 国家海洋局天津海水淡化与综合利用研究所, 天津 300192
}

摘要: 研究发现微生物燃料电池从启动到稳定运行的过程中往往存在一种现象, 就是在高电流密度下, 微生物燃料电池的输出电 压会出现逆转, 从而限制了微生物燃料电池的规模化应用, 以及它在污废水处理、脱盐等方面的功能.

前期研究发现, 微生物燃料电池的性能逆转现象与阳极材料的电容性能有关. 电极材料的电容越大, 越有利于微生物燃料电 池的产电性能稳定, 换言之, 阳极材料电容不足导致产电性能逆转. 但是超级电容活性炭的制作工艺繁琐, 成本高, 且导电性弱, 不能满足微生物燃料电池的应用需求. 炭黑的导电能力强、化学稳定性高、成本低, 但作为微生物燃料电池的阳极则产生产电性 能逆转现象.

化学修饰(如酸、碱活化或者添加具有赝电容性质的金属氧化物等)可以提高材料的电容性能. 低温条件 $\left(80{ }^{\circ} \mathrm{C}\right)$ 下, 对低电容 材料一炭黑进行 $\mathrm{HNO}_{3}$ 和 $\mathrm{KOH}$ 的化学活化处理, 并在此基础上, 进一步用 $5 \% \mathrm{Fe}_{3} \mathrm{O}_{4}$ 修饰, 采用辊压工艺, 以质量分数为 $60 \%$ 的聚四 氟乙烯乳液为粘结剂, 制作微生物燃料电池的阳极, 与空气阴极构建单室微生物燃料电池系统. 采用傅里叶变换红外光谱(FTIR)、 比表面积测试、材料表面 $\mathrm{pH}$ 和X射线能量分析光谱(EDX)等手段表征炭黑活化前后的物理、化学性质; 接触角润湿性测试表征活 化前后电极表面的亲疏水性. 电化学循环伏安法测试活化前后, 电极的电子存储能力.

与蒸馏水的 $\mathrm{pH}$ 相比较, 材料表面 $\mathrm{pH}$ 分析表明炭黑材料经化学活化处理后, 其表面 $\mathrm{pH}$ 无明显变化; FTIR和EDX测试表明化学 活化处理使得炭黑表面引入含 $\mathrm{O}(\mathrm{N})$ 官能团; 吸附-脱附曲线分析表明化学活化后, 炭黑的比表面积减小, 微孔与介孔的体积比增 加; 接触角测试表明炭黑阳极活化处理后, 电极表面亲水性增加; 循环伏安测试证实, 化学活化后的炭黑阳极电容得到0.1-0.8 $\mathrm{F} / \mathrm{cm}^{2}$ 的增长. 结合燃料电池的产电性能测试, 发现只有当炭黑阳极电容不小于 $1.1 \mathrm{~F} / \mathrm{cm}^{2}$ 时, 微生物燃料电池的产电逆转现象才会 消失. 炭黑阳极的化学活化方法为微生物燃料电池的性能稳定提供了一种简便、低成本的方法.

关键词：微生物然料电池; 化学活化; 四氧化三铁; 阳极电容; 产电行为

收稿日期: 2015-01-12. 接受日期: 2015-04-22. 出版日期: 2015-08-20.

*通讯联系人. 电话: (022)87897992; 传真: (022)87897993; 电子信箱: pxinhong@126.com

基金来源：国家自然科学基金(51409052); 上海同济高廷耀环保科技发展基金会.

本文的英文电子版由Elsevier出版社在ScienceDirect上出版(http://www.sciencedirect.com/science/journal/18722067). 